\title{
Assessment of the quality of work of personnel in russian health resort institutions
}

\author{
Glyusa Bakieva*, Anna Bannova \\ Bashkir State University, Ufa, Russia
}

\begin{abstract}
The article substantiates the relevance of the activities of sanatorium-resort enterprises due to the pandemic. The dynamics of development of medical tourism is provided. The role of personnel in business efficiency is highlighted. Methods and indicators for analyzing the quality of personnel work are provided. A quantitative review of the sanatoriums of the Republic of Bashkortostan is provided. The intangibility of the spa service makes it impossible to study and evaluate before its receiving. This leads to difficulties in managing a specific service. Direct contact between the personnel and the guest is key for the enterprises of the spa industry. Therefore, the quality assessment will depend on many subjective and objective factors. On the example of a particular sanatorium, the quality of the work of the personnel was assessed and the factor analysis of the dissatisfaction of the clients with the work of the personnel with the Pareto diagram was carried out. Three main problems fell within the $80 \%$ range. Measures are proposed to improve the quality of work of personnel in sanatorium-resort institutions.
\end{abstract}

\section{Introduction}

The health resort issue is very important at the present time. This is due to the fact that since March 2020 they functioned as observators, and since 2021 they began to actively implement rehabilitation programs after the COVID-19 infection. The dynamics of demand for rehabilitation tours is positive and has a growth rate of $15-20 \%$ weekly [1.13]. There is a rejuvenation of the contingent of vacationers in sanatoriums, probably due to the closure of borders or the desire to improve their health while on vacation. The pandemic has changed the values of young people, a healthy lifestyle is coming to the fore.

Medical tourism is progressing and the annual growth rate is $20-30 \%$. The share of tourists traveling in order to obtain modern medical care is $40 \%$ of the total world number of tourists, and $32 \%$ are looking for a better healthcare system. In developed and developing countries, health care services are notable for accessibility only to wealthy people, the opportunity to receive high-quality treatment, combined with recreation in excellent centers, encourage tourists to seek affordable medical services around the world, despite the existing "COVID" restrictions. Almost $15 \%$ seek to find more operative

\footnotetext{
*Corresponding author: bgr85@mail.ru
} 
methods of treatment, and only $9 \%$ set the task of obtaining cheap high quality medical services [10].

The current participation of the Republic of Bashkortostan in the export of sanatorium and resort services is characterized by an extremely low degree of activity, weak use of competitive advantages. This area belongs to the one where the level of value added is relatively high.

The successful functioning of the enterprise is possible if all elements of the system work effectively. The personnel management system is a priority in the efficiency of the enterprise. The philosophy of work with "human capital" adopted in the organization, expressed in the optimization of its structure, cost, development, and determines the principles that are reflected in the personnel policy [14].

\section{Study Methods}

Methods for assessing the quality of personnel (personnel work) are conventionally divided into three types: qualitative, quantitative and combined.

The qualitative method is based on the study of the employee, the analysis of the quality of his/her work [7].

This method includes:

- assessment of the performance of tasks (how well the employee performs his duties);

- matrix method;

- the method of the system of arbitrary characteristics (we take as a basis the strongest points and notable achievements of the employee and form a general opinion);

- group discussion.

Quantitative methods already include more accurate data, because what can be calculated can be changed. It includes:

- scoring method;

- ranked method.

Combined methods combine qualitative and quantitative assessments. The comprehensive assessment is obviously the most complete and reliable. It represents:

- the method of the sum of evaluations (we evaluate all the characteristics of the employee that are important for the position, and then we form the average. Compare it with the "ideal";

- grouping system (we group employees by efficiency: from the most ineffective to the leaders. Then we are already looking whom to fire from the first group and whom to promote from the second one).

Examples of criteria for assessing the quality of personnel work are provided in Table 1.

Table 1. A sample of personnel assessment according to the criteria.

\begin{tabular}{|c|c|c|c|}
\hline Criteria for & High importance & $\begin{array}{c}\text { Medium } \\
\text { importance }\end{array}$ & Low importance \\
\hline Discipline & + & & \\
\hline Quality of work performed & + & & \\
\hline Scope of work performed & + & & \\
\hline Professional knowledge & + & & \\
\hline Leadership skills & & + & \\
\hline High labor productivity & + & & + \\
\hline Creation & & & \\
\hline
\end{tabular}

It is necessary to describe the criteria. Using a scale for evaluating some of the criteria of an already defined employee using a point system. For example, 1 point - does not meet 
the requirements, 2 points - does not always meet the requirements, 3 points - fully meets the requirements.

Next is the grouping and ranking of criteria.

The data obtained will clearly demonstrate the level of quality of work of an employee of the enterprise.

To analyze the movement of the labor force, it is important to determine the average headcount. Further, a systematic analysis of the indicators is carried out: the turnover ratio for personnel recruitment $(\mathrm{Kpr})$; personnel retirement turnover ratio $(\mathrm{Kv})$; personnel turnover rate $(\mathrm{Kt})$; the coefficient of the total personnel turnover $(\mathrm{Kob})$; the turnover of employees plays an important role in the activities of the enterprise.

To assess social results, the coefficients of permanence and stability of personnel are also studied: coefficient of permanent composition of personnel (Kps); personnel stability coefficient (Kst). They characterize the compliance of the level of remuneration and working conditions, labor and social benefits with the expectations of employees.

To assess the effectiveness of human resources management, the fund of working time is often used, measured in man-days, man-hours.

The calculation of labor productivity indicators characterizes the organization's activities by the ratio of the output (service) to the resources spent on it. Labor productivity is a versatile tool that is equally effectively used to calculate the performance of work for any given time period.

The most common formulas are listed below:

1) $\Pi \mathrm{T}=\mathrm{O}_{\mathrm{n}} / \mathrm{P}_{\mathrm{cp}}$, where $\mathrm{O}_{\mathrm{n}}$ - the volume of products manufactured (in kind or in monetary terms) $; \mathrm{P}_{\mathrm{cp}}$ - the average number of employees in the production of this volume of products;

2) $\Pi \mathrm{T}=0_{n} / B_{n}$, where $O_{n}$ - the volume of products manufactured (in kind or in monetary terms); $\mathrm{B}_{\mathrm{n}}$ - the time spent on the production of products (hour, day, month, and etc.).

Also, labor productivity is sometimes called the cost of working time per unit of output. That is, it is an indicator of the labor intensity of production. This is a value that is inversely proportional to the amount of production:

$\mathrm{T}=3_{\mathrm{T}} / \mathrm{O}_{\mathrm{n}}$, where $\mathrm{T}-$ the labor intensity; $3_{\mathrm{T}}-$ labor costs; $\mathrm{O}_{\mathrm{n}}-$ the volume of products produced.

\section{Results of the Study}

A sanatorium-resort product (a complex of services and goods of a sanatorium for a negotiated price of a voucher) is a complex multi-level concept described using the attributive theory of the product of T. Levitt -F. Kotler. A spa product is understood as a multi-attribute model (Figure 1), graphically resembling a target with concentric circles [12]. 


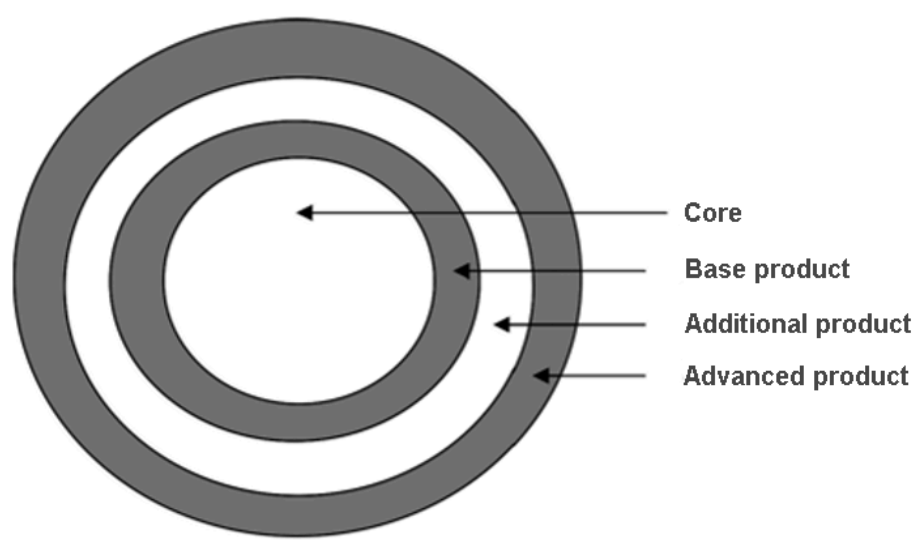

Fig. 1. Multi-Attribute Model of a Spa Product.

The intangibility of the spa service makes it impossible to study and evaluate before receiving. This leads to difficulties in promoting a specific service. Direct contact between the personnel and the guest is key for the enterprises of the spa industry. The client perceives the service as a result of the activities of the sanatorium personnel, and subsequently on the dynamics of health improvement.

Managers and employees of sanatorium and resort institutions mainly adhere to the work of internal marketing tools (recruitment and training of competent personnel; retention of customer-oriented personnel, performing their work ensuring high quality) $[1,4,8]$.

Estimating the number of health resort institutions in the Republic of Bashkortostan, a total of twenty-six health resort organizations shall be singled out. Of these, nine sanatoriums for the improvement of the adult population (Assy, Zelenaya Roscha, Karagai, Krasnousolsk, Yumatovo, Tanyp, Talkas, Yangan-Tau, Yakty-Kul) and one year-round health and wellness camp Salyut; thirteen sanatoriums for children: one for antituberculosis (Tolpar), two for pulmonary (Mechetlinsky district, Ishimbay), two neuropsychiatric (Akbuzat, Nur), eight multidisciplinary (Krasnousolsky, Pavlovsky, Sakmar, Istok, Raduga, Tally-Kul, Ural, Duslyk); three anti-tuberculosis sanatoriums for adults of federal subordination (named after S.T. Aksakov, Glukhovskaya, Shafranovo) [9].

The assessment of the activities of the most popular sanatorium-resort institutions in terms of the dynamics of proceeds per one rested is presented in the figure. 


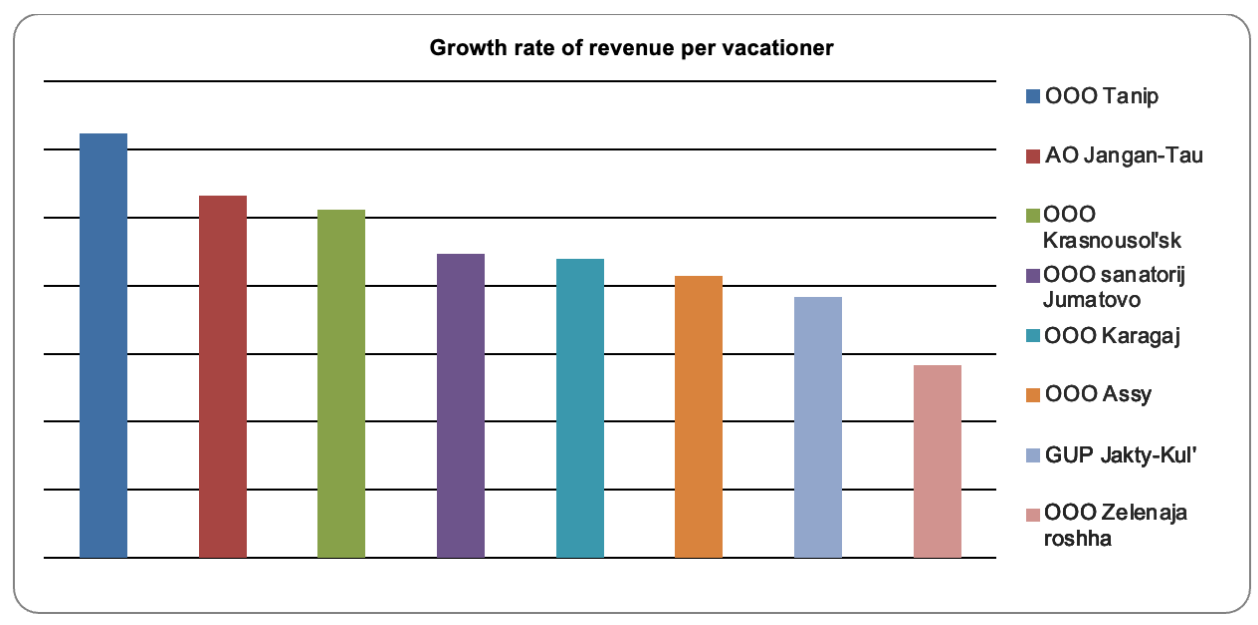

Fig. 2. Growth rate of revenue per vacationer.

The analysis of the sanatoriums showed a high level of capital intensity, a long payback period, a high share of fixed assets in the structure of assets.

Using the example of GAUZ RPNS Akbuzat, we will consider the quality of personnel work. State autonomous health care institution Republican psycho-neurological sanatorium for children, including for children with parents Akbuzat is an enterprise aimed at providing psychotherapeutic assistance and psychological correction to children in need.

The cost structure of the sanatorium is presented below.

Table 2. The cost structure of the sanatorium (thousand rubles).

\begin{tabular}{|c|c|c|c|c|}
\hline & \multicolumn{3}{|c|}{ Structure, in \%. } & \multirow{2}{*}{$\begin{array}{c}\text { Growth rate } \\
\text { 2020 } 2018 \\
\text { (\%) }\end{array}$} \\
\cline { 2 - 5 } & 2018 & 2019 & 2020 & \\
\hline Salary and social security contributions & 58.09 & 58.48 & 61.54 & 98.64 \\
\hline Medication & & & & 153.59 \\
\hline Household expenses & 1.44 & 1.46 & 2.38 & 86.39 \\
\hline Write-off of materials & 3.79 & 3.44 & 3.51 & 97.11 \\
\hline Depreciation of fixed assets & 5.14 & 5.41 & 5.36 & 60.89 \\
\hline Repair costs & 5.97 & 4.47 & 3.91 & 156.23 \\
\hline Administrative expenses & 6.90 & 6.53 & 11.58 & 188.63 \\
\hline Taxes and fees & 0.07 & 0.06 & 0.14 & 87.77 \\
\hline Other expenses & 0.07 & 0.06 & 0.06 & 64.79 \\
\hline TOTAL costs & 19.98 & 21.55 & 19.90 & 93.11 \\
\hline
\end{tabular}

From the above table, we can conclude that, comparing 2020 and 2018, we see a decline and a negative value of indicators such as wages and social security contributions, 
business expenses, write-offs of materials, and etc. This is confirmed by the fact that it was in 2020 that the period of worldwide coronavirus infection began: a certain number of workers were laid off (or transferred to partially paid vacations), and the cost of household materials was lower. Other expenses also decreased in comparison with 2019 and 2020 by $1.65 \%$. Therefore, comparing 2018 and 2020, we can conclude that most of the indicators turned negative and began to decline due to the spread of the coronavirus infection COVID-19.

The company has a high percentage of personnel constancy $(97.78 \%)$, as well as a high percentage of security is determined by such indicators as "hired" $(82.50 \%)$ and "worked all year" (79.44 \%). Therefore, we can talk about the high availability of labor resources of the investigated enterprise GAUZ RPNS Akbuzat.

Movement of personnel to enterprises is described in more detail in the table below.

Table 3. Indicators of staffing movement.

\begin{tabular}{|c|c|c|c|}
\hline Coefficient name & $\begin{array}{c}\text { Percentage value of } \\
\text { the coefficient (\%) for } \\
2018\end{array}$ & $\begin{array}{c}\text { Percentage value of } \\
\text { the coefficient (\%) for } \\
2019\end{array}$ & $\begin{array}{c}\text { Percentage value of } \\
\text { the coefficient (\%) } \\
\text { for 2020 }\end{array}$ \\
\hline $\begin{array}{c}\text { Recruiting turnover } \\
\text { coefficient }\end{array}$ & 21.84 & 20.89 & 18.75 \\
\hline $\begin{array}{c}\text { Disposal turnover } \\
\text { ratio }\end{array}$ & 31.7 & 30.84 & 32.9 \\
\hline $\begin{array}{c}\text { Employee turnover } \\
\text { rate }\end{array}$ & 28.25 & 26.87 & 67.1 \\
\hline $\begin{array}{c}\text { The coefficient of the } \\
\text { constancy of the } \\
\text { composition of the } \\
\text { enterprise personnel }\end{array}$ & 68.3 & 69.16 & \\
\hline
\end{tabular}

Based on the data in Table 3, we can conclude that over the past three years, the highest coefficient in the organization of GAUZ RPNS Akbuzat is the coefficient of the constancy of the enterprise personnel for 2019 (89.55\%). For 2018 and 2020, this ratio also takes high percentages, which indicates a normal, stable state of the organization's staffing.

A working group for quality has been formed in the sanatorium. Each structural unit has appointed a quality representative.

The structure of personnel by age for the last year is $0.57 \%$ under the age of 20 , the share of employees belonging to the age group from 20 to 30 is $5.11 \%$, at the age of 30 to $40-24.43 \%$, from 40 to 50 years old $-26.14 \%$, employees over 60 years old $-18.75 \%$. 


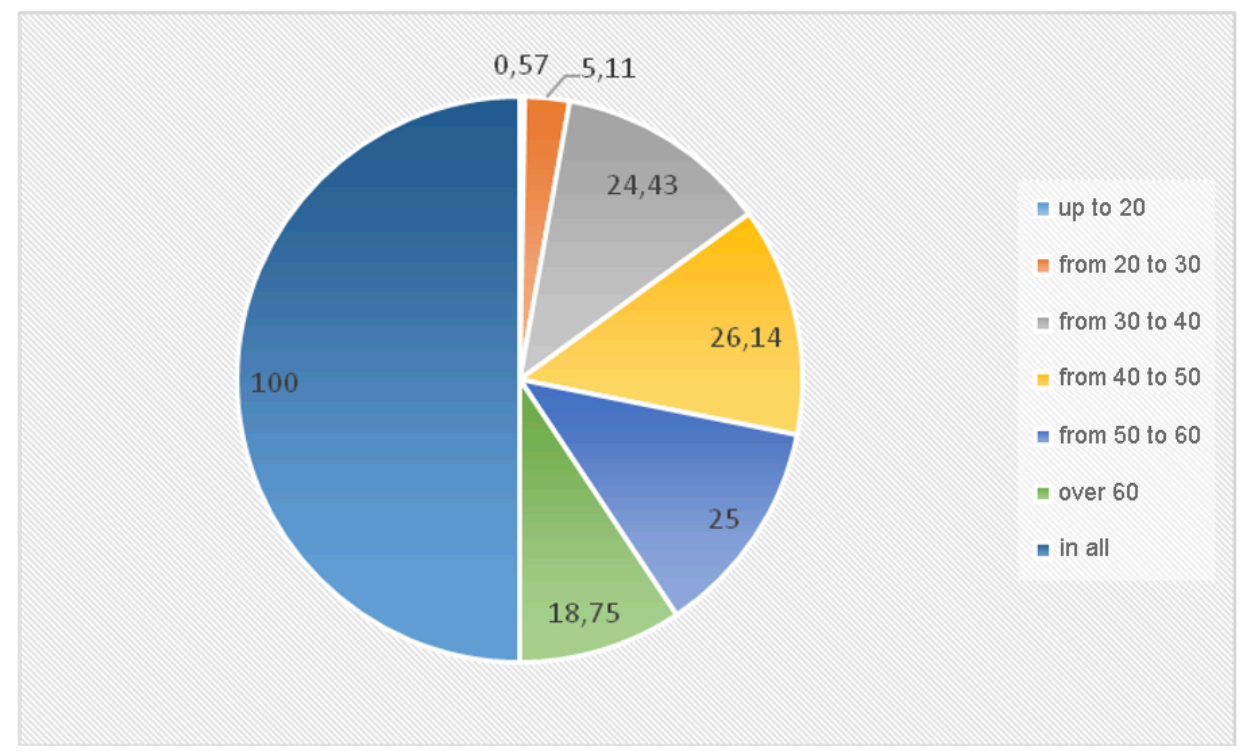

Fig. 3. Personnel structure by age, $\%$.

A large percentage of the personnel have been working in the sanatorium from the very opening (for 10 years of work experience and more $-89.21 \%$ ).

Table 4. The rate of growth of labor productivity and the wage fund of the enterprise.

\begin{tabular}{|c|c|c|}
\hline Indicator & $\begin{array}{c}\text { Growth rate, 2020 to } \\
2018 \\
(\%)\end{array}$ & $\begin{array}{c}\text { Growth rate, } \\
2020 \text { to 2019 } \\
(\%)\end{array}$ \\
\hline Labor productivity & 59.71 & 47.11 \\
\hline Enterprise wages fund & 107.34 & 106.34 \\
\hline
\end{tabular}

From the data provided in the table, we can conclude that over the past three years, labor productivity has been falling, despite the fact that the wages fund of the enterprise continues to increase. The continuation of this situation may lead to a deterioration in the financial situation of the enterprise.

The quality management system of GAUZ RPNS Akbuzat is recognized as meeting the requirements of the international standard ISO 9001:2015. This is the conclusion reached by the auditors of the International Certification Body G-CERTi.

Based on the results of the audit, a certificate of conformity was issued on December 21, 2019 for the period of 3 years. During these three years, the sanatorium will have to undergo an annual inspection control. The scope of certification included provision of spa services, provision of rehabilitation and additional education services for children, provision of treatment services for children and their parents.

To study the current state, the prospects for the development of services and analyze the quality of services provided in the Akbuzat sanatorium, we have developed a questionnaire for assessing the satisfaction of consumers $[2,3,4]$.

The analysis of the results of the survey showed that $69 \%$ of the respondents visited the sanatorium for the first time, $24 \%-2$ or more times, and $7 \%$ - were in the Akbuzat 
sanatorium more than 4 times. (fig. 2.3). Therefore, the percentage of satisfied clients wishing to receive the service again is low.

The sanatorium market is very saturated. Therefore, to attract consumers at the enterprise, the organization and methods of studying the demand for services are carried out in two types: accounting for the realized demand for goods sold and accounting for unmet demand, that is, the seller in the service process needs to find out the preferences of consumers.

Next, we will conduct a SWOT analysis as an important component in the marketing management process. We will define a specific list of the strengths and weaknesses of the enterprise, its opportunities and threats, as well as the connections between them, for which we will draw up a SWOT matrix.

Table 5. SWOT-analysis of Akbuzat sanatorium.

\begin{tabular}{|c|c|}
\hline Opportunities & Threats \\
\hline $\begin{array}{l}\text { carrying out complex services in accordance } \\
\text { with the quality standards of sanatorium care; } \\
\text { natural and climatic factors; } \\
\text { improving work efficiency through } \\
\text { innovation. }\end{array}$ & $\begin{array}{c}\text { low incomes of the majority of the population; } \\
\text { increased competition on the part of rivals who } \\
\text { more quickly adapt to changes in consumer } \\
\text { preferences; }\end{array}$ \\
\hline Strengths & Weaknesses \\
\hline $\begin{array}{l}\text { reliable experience in the spa services market; } \\
\text { funding from the state; } \\
\text { location in a suburban ecologically clean area; } \\
\text { licensing and certification of services; } \\
\text { a high level of qualifications of the company's } \\
\text { executives and all personnel in general; } \\
\text { year-round operation of the sanatorium; } \\
\text { presence of a leisure center for children and } \\
\text { their parents. }\end{array}$ & $\begin{array}{c}\text { a high degree of wear and tear of medical } \\
\text { equipment; } \\
\text { lack of capture of a new target audience; } \\
\text { the medical personnel is not supported by } \\
\text { housing; } \\
\text { long distance to the city; } \\
\text { lack of flexible working hours; } \\
\text { lack of advertising; } \\
\text { difficult transport accessibility. }\end{array}$ \\
\hline
\end{tabular}

Let's consider the main points of this analysis. One of the characteristics of the Akbuzat sanatorium's strength is the natural and climatic factors and location in the suburban ecologically clean area. Therefore, the advertising campaign should be aimed at informing consumers about the services of the Akbuzat sanatorium and thereby explain the high cost of the services provided.

Analyzing the strengths and weaknesses, as well as opportunities and threats, it is possible to put forward a strategy for promoting the sanatorium Akbuzat - SO - a combination of "strength" and "opportunity". Since with a competent approach to advertising and sales, you can significantly increase sales levels (possible sale of vouchers in the future, via the Internet).

To identify more significant shortcomings related to the quality of work of the employees of the investigated sanatorium, a questionnaire for clients was developed. The survey involved children over the age of 14 who were sent for treatment to this sanatorium, and adults who were under the "Mother and Child" program. 


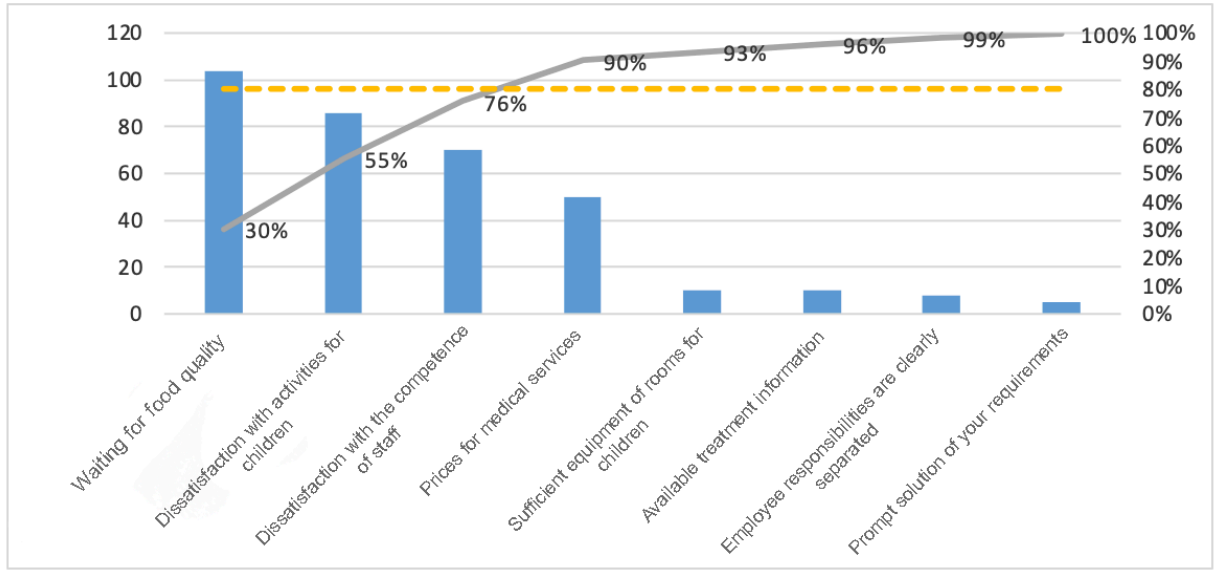

Fig. 4. Pareto chart for a survey of consumer dissatisfaction with the quality of personnel work.

Figure 4 shows significant problems that the investigated sanatorium needs to pay special attention to and take measures to eliminate them.

\section{Discussion}

The results showed that three main problems fell within the $80 \%$ range: expectation of high quality food (poor, monotonous); dissatisfaction with animation activities; dissatisfaction with the competence of some personnel.

The company, at its discretion, can improve the situation by organizing:

1) passing by employees of additional training, refresher courses, including on animation events;

2) arrangement of a new room for self-development of children. It shall be equipped with complete creative equipment (purchase of a good drawing board; arrangement of specialized workplaces for the development of children's motor skills; purchase of a set of a wider range of board games, and etc.);

3) improving and expanding the menu of the diet (adding new dishes that are more interesting for children; more original serving of dishes, for example, a dish from the head chef at the end of the arrival of the teams; minimizing dishes and products that are not in demand among children and their parents;

4) separate implementation of activities for children of younger and preschool age from children of an older age category;

5) constant monitoring by the top management of the quality of satisfaction of children and their parents with the competence and politeness of the personnel (conducting additional surveys, compiling an analysis based on survey data and conducting educational conversations with personnel, based on the results of the analysis obtained);

6) development of internal standards for employees, in which all their job responsibilities will be strictly spelled out and separated;

7) introduction of a system contactless NFC program, which will be easy to use and will be able to allow vacationers to find out all the information they are interested in about this sanatorium, using only a mobile phone and a barcode of the organization, without flipping through paper documents $[5,10]$;

8) payment of incentive bonuses according to a point rating system (criteria: ability to plan working hours, organization, absence of conflicts in the team, efficiency, absence of complaints from the consumer, a certain contribution to the activities of the organization). 
9) acquisition of more high-performance equipment in order to increase the speed of patient care.

Own and borrowed funds, including private investments, can serve as a source for carrying out the above measures.

In general, many sanatoriums are characterized by similar problems that require an early solution.

By introducing the above measures at the enterprise, it is possible to improve the image, expand the client base and obtain a significant economic effect. For example,

1. Purchase of new equipment - Apparatus for vacuum-roller LPG massage and cavitation $\mathrm{S}$ - with a payback period of 6.5 months, will satisfy the need for a range of services and bring additional profit (including taxation) per year in the amount of 200,800 rubles, or the amount received from additional profit to direct the payment of bonuses to employees - the amount for the payment of bonuses will be 193,077 rubles.

2. Purchase of new equipment - a KN-80 paraffin melting tank with a larger capacity $(80 \mathrm{~kg} / \mathrm{h})$ will double the number of patients served (due to the larger capacity of the device).

3. Passage of refresher courses for employees. The net annual economic effect received by the enterprise will be 251,000 rubles.

\section{Conclusion}

A study of the quality of work of the personnel of a children's sanatorium-resort institution from the point of view of consumers of services showed that the most dissatisfaction is associated with the menu; with animation activities; poor competence of nursing personnel. The enterprise has an excellent moral and psychological climate, an active personnel policy. Normal personnel turnover is not related to wages and working conditions, but is provoked by remoteness from the city and family circumstances. The results obtained can be used by public authorities to enhance the demand for domestic health tourism.

\section{References}

1. A. M. Al-Awadhi, K. Alsaifi, A. Al-Awadhi, S. Alhammadi, Death and contagious infectious diseases: Impact of the COVID-19 virus on stock market returns, Journal of Behavioral and Experimental Finance, 27 (2020)

2. G. R. Bakieva, L. F. Muftieva, Management analysis as means of improving the business processes at the tourist enterprise: a case study, International Journal for Quality Research, 4, 761-768 (2016)

3. E. P. Borneman, E.G. Salisheva, Z.A. Hamadeeva, The pricing and billing hotel services, Education Transformation Issues, 2, 81-87 (2018)

4. M. S. AlAli, COVID-19 Infection and Mortality Rates Effect on Asian Stock Markets Returns, Sochi Journal of Economy, 14 (2), 227-230 (2020)

5. R. Míková, Analýza dodavatelsko-odbèratelských vztahů v českých firmách Analysis of Supplier-customer Relations in Czech Companies, Výkonnost' podniku, 2, 6-17 (2012)

6. M. N. Galina, L. B. Zhuravleva, G. D. Nubaryan, Aktual'nye voprosy razvitiya sanatorno-kurortnoj sistemy Rossijskoj Federacii, Vestnik SGUTiKD, 4 (18), 77-88 (2011)

7. G. R. Bakieva, A. V. Bannova, R. M. Hakimov, Effektivnost' trudovoj deyatel'nosti v cifrovoj ekonomike, Vestnik Povolzhskogo gosudarstvennogo universiteta servisa 4 (63), 11-18 (2020) 
8. G. R. Bakieva, A. V. Bannova, Obespechenie organizacionnogo razvitiya proizvodstvennogo predpriyatiya na osnove uluchsheniya kachestva produkcii, Vestnik povolzhskogo gosudarstvennogo universiteta servisa, 4 (58), 78-83 (2019)

9. A. A. Bakirov, Zdravnicy Bashkortostana: krasota prirody, sovremennoe oborudovanie, bol'shie ozdorovitel'nye vozmozhnosti i kachestvennyj servis, Kto est' kto v medicine, 2 (85), 72 (2017)

10. M. V. Varakulina, Sistema upravleniya personalom predpriyatiya: konceptual'naya model' i mekhanizm ee realizacii: monografiya (2019)

11. A. Gridasov, Metody i kriterii ocenki personala: kak ocenit' rabotu sotrudnikov v organizacii (2020). Access mode: https://blog.calltouch.ru/otsenka-personala-metodykriterii-otsenki-raboty-personala-v-organizatsii/

12. A. R. Zaripova, G. R. Bakieva, Analiz dohodov naseleniya Rossijskoj Federacii kak pokazatelya blagosostoyaniya strany, Mekhanizm realizacii strategii social'noekonomicheskogo razvitiya gosudarstva. Sbornik materialov XI Mezhdunarodnoj nauchno-prakticheskoj konferencii, 108-110 (2019)

13. A. M. Vetitnev, Ya. A. Vojnova, Organizaciya sanatorno-kurortnoj deyatel'nosti: uchebnoe posobie (2017)

14. R. Kil'dyushkin, COVID i more: $20 \%$ sanatoriev v RF nachali postinfekcionnuyu reabilitaciyu (2021). Access mode: https://iz.ru/1120263/roman-kildiushkin/covid-imore-20-sanatoriev-v-rf-nachali-postinfektcionnuiu-reabilitatciiu 